VOL. XI, NO. 12.-BOTANICAL GAZETTE.-DEC., 1886.

The Bulliform or Hygroscopic ('ells of Grasses and Sedges compared."

\author{
W. J. BEAL.
}

( WITH PLATE $\mathrm{X}$.)

As so little attention has been given to this topic, it will be necessary first to describe briefly the leaf of a grass. In general, it consists of a sheath encircling the stem, and a lamina spreading from the upper part of the sheath. The blade is traversed longitudinally by fibro-vascular bundles which vary much in size and degree of perfection. In viewing a magnified transverse section of a mature leaf of Sesleria (fig. 1), we see: $e$, an outer envelope of cells, the epidermis; $b$, the median fibro-vascular bundle; $h, h$, lateral bundles; $a$, the lower median strand of hypodermal fibers; $d$, the upper median strand; $c, d^{\prime}$, the lateral strands. The other cells are parenchymatous, most of them containing granules of chlorophyll. The vacancy, $i$, is the lacuna, caused by the rupture of some cells. In aquatic grasses the lacunæ are very large. The epidermal system consists of: $a$, epidermis proper; $f, g$, bulliform (blister) cells; $c$, stomata ; $d$, trichomes.

Of the bulliform cells I speak more particularly. They are in longitudinal parallel lines, are larger, extend further into the leaf, and have thinner walls than ordinary epidermal cells. They are usually more or less wedge-shaped, with the point of the wedge towards the outside of the leaf. When dry, these cells contract and aid in closing the leaf in two or three ways; when moist the leaf expands again. In Zea Mays (fig. 2) these cells are raised above the others and puff out like a blister. When viewed on the surface of the leaf the bulliform cells are usnally seen to have the proportions of length and width much like those next to them.

The number of rows in a species appears to be always uniform, but the number varies with the species from three to twelve in a band. If there are many rows the cells are shallow; if few, the cells are deep; if three only, those at the side are small, and the middle one is very large. The arrangement or plan of these cells is quite constant in a species, but in a genus they often vary widely.

The following examples will give some notion of the variety, the sections being made in the widest part of the leaf:

* Read before the A. A. A. S. Buffalo meeting, 1886. 
1. The leaves of Dactylis glomerata have one median band (fig. 3).

2. In Chloris petræa there is one middle band, and one or more on each side.

3. The leaves of Poa pratensis have two bands, one on each side of the middle (fig. 4).

4. Andropogon squarrosus has one band each side of the midelle and a small one at each edge.

5. The leaf of Phleum pratense has one band of several shallow cells each side of the middle and others between the veins (fig. 5).

6. The leaves of Zea Mays have a band between each two primary bundles and above each third class bundle (fig. 2.)

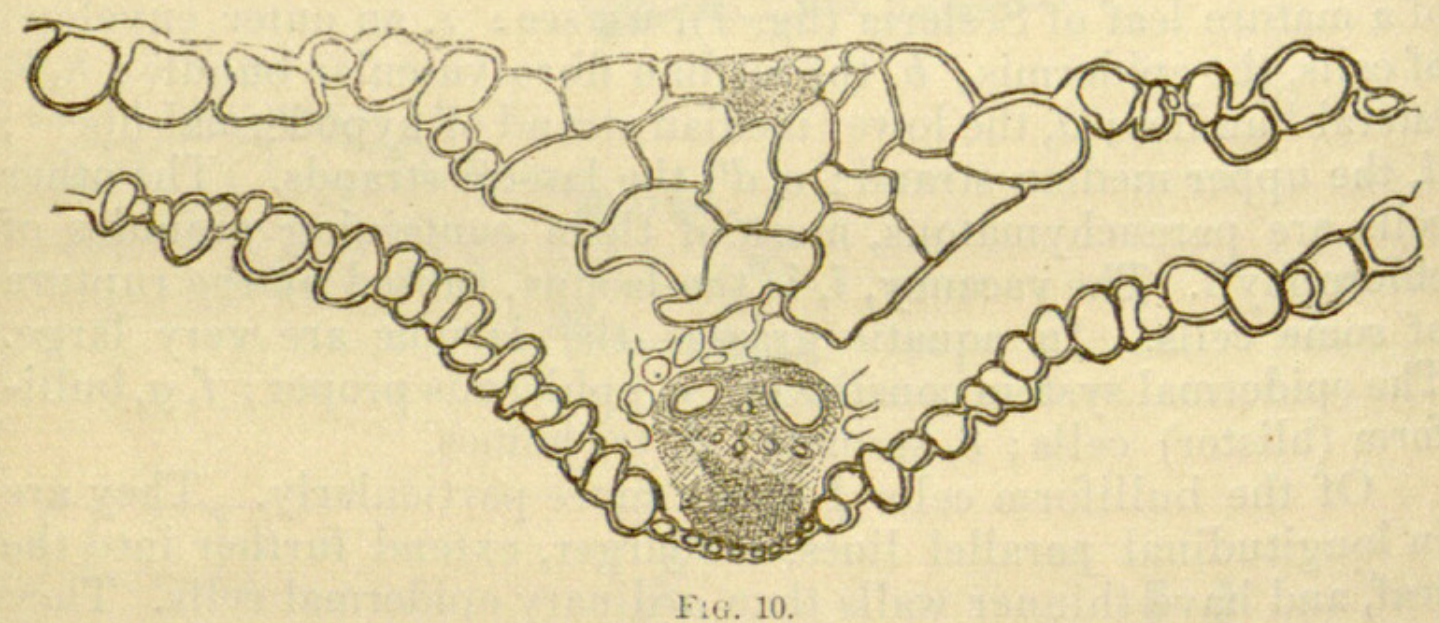

7. The leaf of Leersia oryzoides has numerous bands on the upper surface each side of the middle, and one band each side of the keel on the lower side (fig. 6).

8. The leaf of Amphicarpum Purshii has opposite bands of bulliform cells on both surfaces, though those above are most prominent (fig. 7 ).

9. In case of the leaves of Panicum plicatum the bands of bulliform cells are first on the upper side and then on the lower, and are found in grooves (fig. 8).

10. The leaf of Andropogon prinoides has large epidermal cells of nearly uniform size distributed all along the surface, excepting over the veins (fig. 9).

11. The leaf of Paspalum plicatum has a very irregular epidermis, with groups of cells in the center of the leaf, several above each other, as well as side by side, all acting as bulliform cells (fig. 10, text).

In vernation the leaves take the same positions as when full grown and dried, though the bulliform cells at that time are very 
small. The leaves of Dactylis and Poa pratensis are conduplicate when slowly dried, while those of Phleum are convolute. The leaves of Panicum plicatum, when dry, close in a zigzag manner like a fan. The object accomplished by the closing or rolling of the leaves is to cover one surface and assist in preventing excessive evaporation in dry weather.

The examples here cited belong to various genera and tribes of grasses, and give a fair idea of the varied forms of bulliform cells, though these are by no means all the varieties that might be shown.

In a similar manner let us now glance at some of our common species of Cyperaceæ, and compare them with some leaves of grasses.

1. The leaf of Cyperus rotundus, var. Hydra, is narrow and thin, having a single deep band of bulliform cells above the midvein (fig. 11). The epidermal cells are rather large and nearly uniform in size. The bulliform cells are much like those of Dactylis glomerata. The epidermal cells on the upper side are much larger.

2. In case of Kyllingia pumila the upper epidermis occupies nearly half the thickness of the leaf, the cells above the midvein being scarcely larger than those on either side (fig. 12). This leaf may be compared with Andropogon prinoides, though in the latter case the epidermal cells over the veins are small.

3. The leaves of Heleocharis, so far as seen, have leafblades which are very small or rudimentary.

4. The leaves of Scirpus sylvestris are wide, with many veins, opposite each one of which, above and below, there is a depression. There is one band of about eight cells above the midvein and these have only a moderate depth. The epidermal cells are rather small and can scarcely act as bulliform eells. The leaf much resembles that of Dactylis glomerata, but the bulliform cells are not so deep.

5. The blades of Scirpus validus, the great bulrush, are very short, almost rudimentary. The lacunæ are large and near the upper surface of the leaf. The cells of the upper epidermis, as well as several layers below, are rather small, thin-walled, not varying much in size. All of these small cells act as bulliform cells and the leaf becomes convolute or involute when drying.

6. The leaves of Fimbristylis autumnalis (fig. 13) have a thick epidermis of one layer of thin-walled cells, which extend nearly to the lower side of the leaf. This much resembles the leaf of Andropogon prinoides, thous h in the latter the cells over the veins are snall. 
7. On examining a leaf of Eriophorum Virginicum we see that it is very thick, with many veins and lacunæ. The epidermis is composed of small cells; the single band of bulliform cells: over the midvein consists of about eight rows of considerable depth. The epidermal and bulliform cells are much like those of Dactylis glomerata.

8. In Fuirena squarrosa the cells of the upper epidermiextend about one-third the depth of the leaf and are somewhat uniform in size. There is no special enlargement of these cells above the midvein. The epidermis is much like that of Fimbristylis autumnalis and Kyllingia pumila among sedges, and Andropogon prinoides among grasses, except the cells above the leading veins are as large as any, while in the grass they are very small over the veins.

So far the examples of leaves of sedges noticed belong to one tribe, Scirpeæ.

9. The leaves of Rhynchospora capillacea (fig. 14) are very narrow, with a few veins, small epidermal cells, and a band of bulliform cells reaching more than half way across and extending nearly one-third the depth of the leaf. This may be compared to a very narrow leaf or the apex of a leaf of Dactylis.

10. The leaf of Cladium mariscoides is rather thick, becom. ing thinner at the margins and toward the midvein. The epidermal cells are small and have thin walls; there are many layers of similar thin-walled parenchyma cells below the epidermis; but no distinct band of bulliform cells. The leaf reminds us very much of the leaf-blade of Scirpus validus.

The last two examples belong to the Rhynchosporeæ.

11. The bulliform cells of Scleria triglomerata are much like those of Carex vulpinoidea (fig. 15).

The following eight examples are selected from the large and difficult genus Carex :

12. The blade of C. vulpinoidea (fig. 15) is of medium thickness, having about six bulliform cells extending one-third the way to the lower side of the broad shallow midvein. Between the veins there is a noticeable enlargement of about six epidermal cells, the other epidermal cells being rather large. These side bands approach in appearance the side bands in Phleum pratense, only they are less distinct.

13. C. lagopodioides has a leaf much resembling the last, but the epidermal cells do not show a resemblance to bulliform cells.

14. C. Grayii is a coarse species found in low and wet plares. The epidermal cells are of moderate size; the lacunæ are large. 
There is one band of bulliform cells of about twelve rows, extending one-half the depth of the leaf, if the deep narrow midvein is not taken into account. So far as bulliform cells are concerned this reminds us of a leaf of Dactylis glomerata.

15. C. Pennsylvanica is an early upland sedge with narrow leaves. The epidermis (fig. 16) is composed of small cells. There are six rows in each bulliform band, and these extend abont two-fifths of the way down to the lower side of the midvein. The epidermal and bulliform cells remind us again of a leaf of Dactylis glomerata.

16. The blade of C. utriculata is very thick, narrowing to the margin and in the center. The epidermal cells are of moderate size; the single band of bulliform cells number about ten and are over the midvein. This leaf reminds us very much of that of Eriophorum Virginicum, but in the former the vessels of the fibro-vascular bundles are near the upper surface, while in the latter they are near the lower side.

17. In the wide coarse leaf of C. Careyana (fig. 17) the upper epidermal cells are rather prominent, varying considerably in size. There is one very wide band of about twenty bulliform cells over the midvein. In the center of the leaf they extend twofifths of the distance to the base of the vein. About half way from the midvein to the margin of each side of the blade there is a longitudinal crest or ridge on the upper side. The prominent vein at this place has small epidermal cells and hypodermal fibers. On the upper surface on either side of this vein and ridge the epidermal cells resemble a wide shallow band of bulliform cells.

18. The leaf of C. Hitcheockiana is much like the last one named, and there are many leaves of Carex proper of like structure.

19. The leaf of C. laxiflora, var. latifolia (fig. 18) is about an inch wide and rather thin. The epidermal cells are somewhat prominent. There is one band in the middle of about ten bulliform cells, which cause this wide leaf to be conduplicate when dry.

In the leaves of Carex the pitted vessels of the fibro-vascular bundles are near the lower side of the leaf.

It will be seen that all the leaves of sedges have been compared with some one of five genera of grasses. In the sedges, so far as studied (many genera of four tribes), I find nothing in the middle of the leaf to compare with that of Poa pratensis, Phleum pratense, Leersia oryzoides, Amphicarpum Purshii, or Panicum plicatum. The bulliform cells and other epidermal cells, the hypodermal fibres, and the lacunæ vary more in grasses than in sedges, or in other words, we find a greater variety of forms of 
these cells or groups of cells in grasses than in sedges. Perhaps we should expect this as most of the sedges thrive in wet places, where the conditions are uniform, while the grasses thrive in a much greater variety of places. Still we find a greater differentiation of parts in the leaves of marsh grasses than in the sedges growing near them.

Some of these characters in the leaves of grasses and sedges may be useful in description and elassification.

Explanation of Plate X.-The drawings are all diagrammatic and represent portions of the tranverse sections of the leaf. Fig. 1, Sesleria cærulea; $a$, median strand of hypodermal fibres; $b$, median fibro-vascular bundle; $c d^{\prime}$, lateral strands of hypodermal fibres; $e$, epidermis; $f$, bulliform cells when leaf is closed; $g$, same when leaf is open; $h h$, lateral fibro-vascular bundles; $i$, lacuna, $\times 120$ (Douval-Jouvé). Fig. 2, Zea Mays, $\times 17$ (Sudworth, in Beal's Grasses). Fig, 3, Dactylis glomerata, $X 38$ (Sudworth, l. c). Fig. 4, Poa pratensis, $\times 75$ (Sudworth, l.c). Fig. 5, Phleum pratense, $\times 20$ (Sudworth, l. c). Fig. 6, Leersia oryzoides, $\times 350$ (Douval Jouvé). Fig. 7, Amphicarpum Purshii, $\times 25$ (Sudworth, 1. c). Fig. 8 , Paricum plicatum, $\times 10$ (Douval-Jouvê). Fig. 9, Andropogon prinoides, $\times 50$ (Douval-Jouvé). Fig. 11, Cyperus. rotundus, var. Hydra, $X 55$. Fig. 12 , Kyllingia pumila, $X 55$. Fig. 13, Fim bristylis autumnalis, $X 55$. Fig. 14 , Rhynchospora capillacea, $X 55$. Fig. 15 , Carex vulpinoidea, $X 46$. Fig. 16, C. Pennsylvanica, $X 55$. Fig. 17, C. Careyana, $\times 55$. Fig. 18, C. laxiflora, var. latifolia, $\times 55$.

\section{Hieroehloa borealis.}

WALTER DEANE.

A visit at Rye Beach, N. H., during the month of August, 1886 , and an aequaintance with an Indian named Sabbatis Dana, who camps in the town every summer and sells baskets and other articles, have given me some interesting facts in regard to the Hierochloa borealis, or Holy Grass. It is one of our widely distributed grasses, ranging over the northern half of the United States and northward. In this section of the country, eastern New England, it is generally found near the sea shore, and is one of our earliest flowering grasses. I have collected it in the middle of May and, at that time, only the culm, rising from the creeping root-stocks, is visible. Later in the season, from the same rootstocks, at intervals of two or three inches, there grow radical leaves in tufts. In the months of July and August these leaves reach their full height. The length of the grass much surprised me, as I can find no mention made of it. I saw it three feet ins 


\section{$2 \mathrm{BHL}$ Biodiversity Heritage Library}

Beal, W. J. 1886. "The Bulliform or Hygroscopic Cells of Grasses and Sedges Compared." Botanical gazette 11(12), 321-326. https://doi.org/10.1086/326044

View This Item Online: $\underline{\text { https://www.biodiversitylibrary.org/item/87716 }}$

DOI: https://doi.org/10.1086/326044

Permalink: https://www.biodiversitylibrary.org/partpdf/221624

\section{Holding Institution}

Missouri Botanical Garden, Peter H. Raven Library

\section{Sponsored by}

Missouri Botanical Garden

\section{Copyright \& Reuse}

Copyright Status: Public domain. The BHL considers that this work is no longer under copyright protection.

This document was created from content at the Biodiversity Heritage Library, the world's largest open access digital library for biodiversity literature and archives. Visit BHL at https://www.biodiversitylibrary.org. 